\section{The University of Illinois at Urbana-Cham-} paign Library has received a $\$ 1.25$ million challenge grant from the Andrew W. Mellon Foundation to fund a senior-level conservator position in its Conservation Unit. The Mellon Foundation grant includes $\$ 1$ million as a permanent endowment and $\$ 250,000$ to establish the new senior conservator position while matching funds are being raised. The University Library has committed to match and exceed the amount of the grant by raising $\$ 1.5$ million over three years. The endowment will generate funding to support the position permanently.

\section{The Historically Black Colleges and} Universities (HBCU) Library Alliance has received a $\$ 70,000$ grant award from the Andrew W. Mellon Foundation for the Alliance's "Preserving Our History" project. The two-year project will document and disseminate the history of the HBCU Library Alliance and highlight member success stories. This is the first grant awarded directly to the Alliance.

\section{Acquisitions}

\section{The Oberman Research Library has been}

acquired by the University of Arizona (UA), following the completion of the endowment of the Heiko A. Oberman Chair in Late Medieval and Reformation History in 2010. Oberman researched and published extensively in his field; his oeuvre includes 17 independent works, 19 edited or co-edited volumes, and 137 articles, prefaces, etc. His most well-

Ed. note: Send your news to: Grants \& Acquisitions, C\&RL News, 50 E. Huron St., Chicago, IL 60611-2795; e-mail:agalloway@ala.org. known works stem from his study of Martin Luther. His book Luther: Man Between God and the Devil (1982)—originally published in German-has been translated into Italian, Dutch, English, and Spanish. After receiving a doctorate in theology in his home city of Utrecht, and being ordained a minister in the Reformed Church of The Netherlands, Oberman accepted a position at Harvard Divinity School, leaving only to assume the directorship of the Institute for Late Middle Ages and Reformation at the University of Tübingen. Oberman was called to the University of Arizona in 1984. Named a Regents' Professor in 1988, he became the founding director of the Division for Late Medieval and Reformation Studies. Oberman's working library of more than 10,000 volumes, some of which are rare, were appraised in 1998 at \$1.2 million. Prior to his passing in 2001, Oberman himself declared that the high ranking of the Division for Late Medieval and Reformation Studies is due largely to students' ability to access this tremendous resource, and it was his intention to bequeath this trove to UA. In what has been called a typically creative gesture however, Oberman made this gift a challenge grant: he would donate his library only upon the creation of an endowed faculty chair within the division. The Heiko A. Oberman Research Library includes more than 100 original Martin Luther texts, more than 60 John Calvin texts, as well as the first collected edition (dated 1545) of Ulrich Zwingli's work, "the crowning glory of a distinguished collection." Zwingli, the first of the "Reformed" Reformers, is thought by some to have had an even greater influence than his counterparts on Western European, and subsequently American, life and thought. The Oberman Library also contains writings from the Second Vatican Council, including drafts of each document produced, as well as final printings. $n$ 